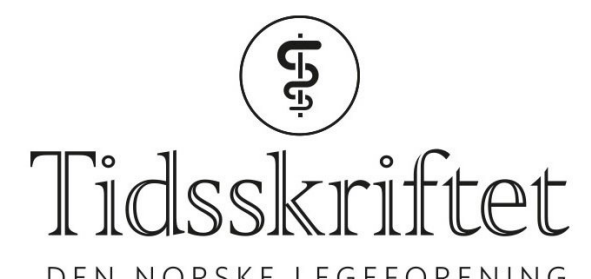

DEN NORSKE LEGEFORENING

\title{
Nøkkel til bedre behandling av kronisk smerte?
}

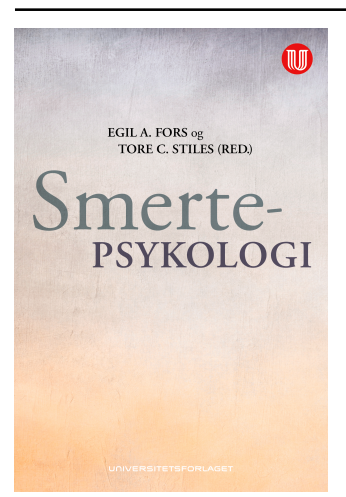

Egil A. Fors, Tore C. Stiles, red.

Smertepsykologi

248 s, tab, ill. Oslo: Universitetsforlaget, 2017. Pris NOK 449

ISBN 978-82-15-02402-8

Smertepsykologi henvender seg til helsearbeidere som arbeider med pasienter med kroniske ikke-kreftrelaterte smerter. Den er en antologi hvor ulike fagfolk i feltet har beskrevet forskjellige metoder for behandling av kronisk smerte, inkludert medikamentell behandling. Boken gir en oversikt over et utvalg av behandlingsmetoder, og er i så måte en introduserende lærebok om disse metodene. Den er også et oppslagsverk, men jeg synes det var nyttig å lese igjennom hele for å få et overblikk, og lærte noe nytt hele veien. Jeg vil også anbefale andre lesere å gjøre det samme.

Kroniske smerter er et stort helseproblem som medfører lidelse og økonomisk tap for både individ og samfunn. Tradisjonell medikamentell behandling har ikke vist seg å være effektiv behandling for mange av pasientene, og det går ofte år før pasienter med kronisk smerte får stilt riktig diagnose. Kanskje kan Smertepsykologi bidra til å øke interessen og kunnskapen om behandlingsmetoder. Jeg tror alle legekolleger, uansett fagfelt, har svært godt av å lese den.

Språket er godt og presenterer tydelig klassifisering og definisjon av hvilken type smerte den omhandler. De forskjellige behandlingsforslagene er presentert med referanser i de aller fleste kapitlene. Det blir derfor ganske tydelig i en liten begrenset del der forventede 
referanser er utelatt. Layout er bra, men noen skjønnhetsfeil på noen sider finnes uten at innholdet forringes.

Jeg savner to felt som ikke er omtalt. Det ene er norske retningslinjer for behandling av kronisk smerte, og det andre er tilgjengelighet av terapimetoder presentert i boka (dvs. hvilke fagmiljøer i Norge har kompetanse på de forskjellige metodene).

Smertepsykologi er svært relevant i allmennpraksis. For leger innenfor somatiske fag er boken også svært nyttig og dekker et felt som statistisk sett forekommer hyppig i klinisk virksomhet. Jeg vil også tro at andre helsefaggrupper vil ha stor nytte av innholdet, spesielt siden terapeuter kan være både leger og andre fagfolk. Den gir en praktisk fremstilling av et komplekst tema på en fin måte, og gir klinikeren en liten introduksjon til evidensbaserte alternativer for behandling av kroniske smerter.

Publisert: 25. mars 2019. Tidsskr Nor Legeforen. DOI: 10.4045/tidsskr.18.0986

(C) Tidsskrift for Den norske legeforening 2020. Lastet ned fra tidsskriftet.no 